\section{O Direito entre a justiça e a piedade: sobre a infidelidade e o desterro de aristocratas e nobres no reino hispano- visigodo de Toledo (636-654)}

\author{
The law between justice and godliness: on the infidelity and \\ banishment of aristocrats and nobles in the Hispanic-Visigoth \\ kingdom of Toledo (636-654)
}

\section{Renan Frighetto*}

\author{
Palavras-chave: \\ Antiguidade Tardia; \\ Reino Hispano- \\ Visigodo de Toledo; \\ Direito; \\ Infidelidade; \\ Desterro.
}

\begin{abstract}
In the Hispanic-Visigoth kingdom of Toledo (VI-VII centuries), the elaboration of the Law started from the royal authority. The Liber Iudiciorum/Lex Visigothorum, a legal compilation associated with the late Roman tradition and published in an organized manner from 654 onwards, presents a variety of legal norms promulgated by the royal power that also involved the problems linked to the breaking of the oath of fidelity between the aristocratic segments and the king. The aristocratic infidelity created serious problems for the king, especially those who fled abroad and attacked the bordering areas of the kingdom. These fugitives, framed in the profile of the outcast, appear in the secular and ecclesiastical legal documentation more broadly and are the object of our analysis in this study.
\end{abstract}

Recebido em: 30/09/2019 Aprovado em: 04/10/2019

\footnotetext{
* Professor Titular de História Antiga da Universidade Federal do Paraná (UFPR). Membro do Núcleo de Estudos Mediterrânicos da UFPR e bolsista produtividade 1-D do CNPq.
} 


\section{As concepções de História, Direito e lei na Antiguidade Tardia Hispana}

\section{A História é feita com documentos (FEBVRE, 1989, p. 249; BARROS, 2019, p. 15- 16). Esta afirmação é, por certo, um mantra para os historiadores, ainda mais se levarmos em conta a famosa afirmação feita por Isidoro de Sevilha nas suas} Etimologias $(I, 41,1)$ de que "História é a narração dos fatos ocorridos, pela qual se conhecem os acontecimentos que tiveram lugar em tempos passados". ${ }^{1}$ Lógico que a explicação oferecida pelo hispalense estava vinculada à tradicional perspectiva da História greco-romana, segundo a qual os verbos "ver" e "conhecer" surgiam como verdadeira força motriz que culminava com a tarefa de preservação do passado legada pelos manuscritos (Isidorus, Etymologiae, I, 43). ${ }^{2}$ Ou seja, para o hispalense, a História, ou o ato de manter viva a memória dos antepassados, se fazia por intermédio dos manuscritos que podemos "ver" e por meio dos quais chegamos a "conhecer" os fatos ali apontados e, evidentemente, selecionados. Por isso, o domínio da Gramática se fazia essencial, "porque às letras se confia tudo que é digno de recordação" (Isid., Etym., I, 41, 2), ainda mais se temos em conta a relação que se estabelece entre o escrito e a verdade, vinculação inquestionável aos autores de História na Antiguidade Tardia. ${ }^{3}$ Perspectiva questionável para nós, herdeiros da tradição historiográfica cientificista da modernidade, como nos aponta Fernández Sebastián (2014, p. 54):

Para el historiador ha dejado de ser posible - si es que alguna vez lo fue - postular la existencia de un punto arquimédico u "ojo de Dios" fuera de la historia, desde el cual observar el pasado y establecer de una vez para siempre "la verdad de los hechos", esto es la interpretación correcta de lo sucedido. Después de Heidegger, Gadamer y Ricouer es impensable entender la historia como un medio externo al historiador, puesto que él mismo es y está en la historia.

Exatamente no equilíbrio da balança entre a compreensão das ideias do passado e a crítica que fazemos hoje daqueles documentos manuscritos se encontra o caminho do conhecimento histórico que, nas palavras de Fernando Gascó (1986, p. 169), é cinético, dinâmico e fascinante.

Se concordarmos com o hispalense que a escrita da História se baseava em textos manuscritos que eram, por sua vez, entendidos como portadores da autoridade do

\footnotetext{
${ }^{1}$ Todas as referências à documentação hispano-visigoda utilizadas ao longo deste estudo foram traduzidas pelo autor. ${ }^{2}$ Adjetivo que significa "habitante de Hispalis (Sevilha)". Neste caso, denominamos Isidoro de Sevilha como hispalense, embora o local exato de seu nascimento seja desconhecido.

${ }^{3}$ Relação estabelecida pelo próprio hispalense ao dizer que "Histórias são fatos verdadeiros que ocorreram; argumentos, acontecimentos que não aconteceram, mas que poderiam ter ocorrido; fábulas, são aquelas que não ocorreram e nem podem ocorrer" (Isid., Etym., I, 44, 5).
} 
passado, a elaboração do Direito seguia uma linha similar. Segundo Norberto Bobbio (1998, I, p. 349), o Direito pode ser definido como "conjunto de normas de conduta e organização voltada à convivência social", reforçando a afirmação isidoriana de que "Direito é um nome genérico; lei é um aspecto concreto do Direito" (Isid., Etym., V, 3, 1). Ou seja, o Direito é amparado em um conjunto de leis que dão a ele materialidade, concretude, visto que a lei "é uma disposição escrita [...] deriva de 'ler', pois está redigida" (Isid., Etym., V, 3, 2). De fato, as leis estavam transcritas nos manuscritos, tendo, como principal argumento, sua base estabelecida no tripé razão/religião/doutrina, elementos que geravam o conhecimento necessário ao ordenamento da vida em comunidade que, na lógica isidoriana, afastava todos da ignorância:

Pois bem, se toda a lei tem seu fundamento na razão, será a lei tudo o que esteja fundado nela, com tal que esteja em acordo com a religião, convenha à doutrina e aproveite à salvação. Se chama "costume" porque são de uso comum (Isid., Etym., V, 3, 4).

Esta concepção "trinitária" da lei, amparada por uma tremenda carga gramatical e retórica, a transformava em um instrumento teórico válido para os grupos sociopolíticos mais destacados, sendo menos efetiva em espaços rústicos e populares. Nestes, os costumes ancestrais tinham uma força e presença efetivas, visto que aqueles faziam parte de "uma prática de longa tradição e referida unicamente aos usos" (Isid., Etym., V, 3, 3), sendo bem mais palpável e reconhecida por seu caráter tradicional e consuetudinário junto daqueles grupos rurais e urbanos tardo-antigos. Contudo, muitos dos usos ancestrais podiam descambar em abusos e violência, na maioria dos casos praticada por aristocratas e nobres que, segundo a lógica dos pensadores tardo-antigos, levariam a comunidade à anarquia e à desordem:

[...] assim como a natureza ignorada e incompreensível da piedade divina se uniu em união de pessoa à condição dos mortais no mistério da redenção humana, nós também, com um fogo parecido, cortemos e arranquemos a raiz dentre os membros desta cabeça o mal da infidelidade e da concupiscência que é a raiz de todos os males e avareza que se confunde com a servidão dos ídolos (Concílio VIII de Toledo, a. 653, c. 10).

Tais "maus atos" praticados por alguns e entendidos como cruéis e contrários à ordem deveriam sofrer a coerção da autoridade constituída e reconhecida, inclusive para que esta mantivesse a sua legitimidade. Uma reação que se fazia por meio do estabelecimento de normas estritas reunidas em códigos legais que seriam aceitos por um conjunto social mais amplo, cujas noções teóricas de consenso e de concórdia tinham 
como objetivo final a convivência pacífica entre todos os súditos, como está indicado no último cânone do IV Concílio de Toledo (a.633, c.75):

Que ninguém excite as discórdias civis entre os cidadãos. Que ninguém prepare a morte dos reis, senão que morto pacificamente o rei, a nobreza de todo o povo em união com os bispos designarão de comum acordo ao sucessor no trono para que se conserve entre nós a concórdia da unidade e não se origine alguma divisão da pátria e do povo a causa da violência e da ambição.

Tanto no mundo imperial romano tardio quanto nas monarquias romano-bárbaras do Ocidente tardo-antigo que Ihe sucederam, cabia à autoridade imperial e depois à régia, em suas respectivas áreas de hegemonia e de influência política, reunir, organizar, atualizar e publicar aquelas normas legais em um único código de leis que seriam válidas e aplicáveis ao conjunto da sociedade (WARMALD, 2003, p. 26-28; FRIGHETTO, 2007, p. 117-121; GROSSI, 2014, p. 160-161). Ao fim e ao cabo, como afirmou o hispalense, o rei que esquece as suas prerrogativas de fazer e aplicar a lei, deixando de exercer seu poder de coerção e de correção, jamais regeria, embora existisse um limite estabelecido pelo "bom juízo da razão" (Isid., Sententiae, III, 48, 7) para que qualquer correção fosse tolerável e aceitável ao conjunto social, sem ultrapassar a barreira da crueldade. Notamos aqui, tanto em termos práticos quanto teóricos, uma evidente herança do passado imperial romano sobre os pilares institucionais do reino hispano-visigodo de Toledo, em particular a necessidade e a obrigação do poder régio de regular e aplicar práticas consuetudinárias que poderiam ser contrárias a seu poder efetivo. Para evitálas, o rei portava e detinha o lus puniendi (PETIT, 1998, p. 218) - o poder de castigar e de punir em matéria jurídica, herdado do imperator romano-tardio -, que se revelava nas penas apontadas nas leis existentes no código jurídico vigente. Tais poderes régios de outorgar, promulgar e impor castigos e penas aos mais variados crimes revelavam um elevado grau de institucionalidade da realeza, que no caso do reino hispano-visigodo de Toledo se materializou, em termos jurídicos, com a publicação de uma nova versão do Liber Iudiciorum/Lex Visigothorum no reinado de Recesvinto, ${ }^{4}$ no ano de 654, que se apresentava como um instrumento legítimo para "corrigir e prevenir a maldade das ações humanas" (Lex Visigothorum, II, 1, 2).

\footnotetext{
${ }^{4}$ O Livro dos juízos nada mais é que a própria Lex Visigothorum atualizada e revisada nos primórdios do reinado de Recesvinto (651-672). Tratava-se de uma nova versão do Codex Revisus publicado no reinado de Leovigildo (568-586) - este, por sua vez, uma versão revisada do Código de Eurico de finais do século V - e que recebeu diversas adições entre os reinados de Recaredo (586-601) e de Chindasvinto (642-651). Portanto, o Liber ludiciorum/Lex Visigothorum surgia, nas palavras de King (1981, p. 37), como "uma compilação revisada". A partir de agora, todas as referências a Lex Visigothorum no texto deste artigo serão apresentadas pela sigla L.V.
} 
Ora, se a lei foi composta para coibir o mal que se pode praticar contra alguém, ou inclusive que já se tenha praticado recentemente, devemos compreender o conceito de maldade nos documentos que estudamos. Sem dúvida que a relação mal/maldade pode encontrar várias explicações, mas nos concentraremos na definição que nos oferecem os documentos de caráter jurídico que buscavam regular as relações de coexistência e de respeito entre os grupos sociopolíticos mais destacados e o poder régio no reino hispanovisigodo de Toledo. Em termos gerais, o mal era entendido como um ato que poderia ser cometido por e contra alguém, possuindo um duplo sentido: se um o cometia, praticava um pecado, se o sofria era porque se Ihe impunha um castigo por algo que havia feito (Isid., Etym., V, 27, 1). Logo, seguindo o pensamento isidoriano, se entendia o mal como uma ação humana provocada pelas atitudes consideradas contrárias à convivência social, comunitária e coletiva, que afetavam os princípios teóricos da concordia e do consenso que eram regedores da vida social e que deveria ser objeto de atenção e de cuidado por parte do rei, visando ao bem-estar coletivo (KING, 1981, p.49). Assim, tais atos direcionados contra um ou vários indivíduos poderiam ser a base de um ato criminoso, que, uma vez realizado, seria reprimido por meio da lei que contemplaria a imposição de várias penas e castigos a eles agregados.

\section{Da fidelidade jurada à infidelidade cometida}

Dos crimes existentes e apresentados na $L$. $V$., nas versões e atualizações feitas nos reinados de Recesvinto (652-672), Ervígio (680-687) e Egica (687-702), chama a nossa atenção o crime de infidelidade cometido contra o rei e que foi considerado pelos bispos reunidos no XV Concílio de Toledo, do ano de 688, como um ato "imperdoável". Aqui, encontramos o ponto de interseção entre as legislações laica e eclesiástica hispanovisigodas no que diz respeito à relação política estabelecida entre os reis e os integrantes da aristocracia e das nobrezas laica e eclesiástica, ${ }^{5}$ que, de fato, baseava-se fortemente nos vínculos e juramentos de fidelidade mútua promovidos no momento da eleição e ascensão dos novos monarcas. Dessa forma, as reuniões conciliares, juntamente com as assembleias régio-aristocráticas, como o ofício palatino e a aula régia, apareciam

\footnotetext{
${ }^{5}$ Seguindo as informações existentes na documentação, verificamos a distinção entre "aristocracia" e "nobreza", em particular quando estabelecemos um paralelo entre ancestralidade e serviço. Nesse sentido, encontramos alguns termos sinônimos, como optimates, primates, maiores e ilustres que evocam superioridade e grandeza de grupos gentilícios hispano-visigodos, os quais denominamos como aristocráticos. Por sua vez, a nobreza possui uma conotação genérica, pois, como nos recorda Isidoro de Sevilha, "Nobilis (nobre): não vil, cujo nome e linhagem é conhecido" (Isid., Etym., $X$, 184). O que separaria o aristocrata do nobre era a sua condição sociopolítica no regnum gothorum, sendo que os nobres poderiam ser denominados como minores ou mediocres.
} 
como espaços de discussões e decisões políticas no reino hispano-visigodo do século VII, nos quais a questão da infidelidade dos segmentos aristocráticos revestia-se de uma grande preocupação, tanto da parte dos agentes episcopais quanto dos integrantes aristocráticos que pertenciam à entourage mais próxima ao rei (FRIGHETTO, 2015, p. 253). Por conta deste grave problema sociopolítico e jurídico, tanto a legislação régia quanto a legislação eclesiástica tentavam impor normas e princípios reguladores das relações entre o rei e a sua sociedade política, definidas por Sanchez-Albornoz (1947, p. 20-27) e Marcelo Vigil e Abilio Barbero (1988, p. 128-135) como "pré-feudais"; ou, no caso de Garcia Moreno (1992, p. 18; 30-33), como "proto-feudais".

É interessante notar que o juramento de fidelidade na Hispania visigoda possuía uma forte carga eclesiástica, cujo reflexo se verificava na elaboração e na escrita das formulae laicas, como a Conditionum Sacramentorum, ${ }^{6}$ que fixava o vínculo de fidelidade mútua entre indivíduos. Recordando uma vez mais o hispalense, poderíamos dizer que se tratava de um juramento coletivo, com duas ou mais testemunhas, no qual se impunha o sacramento como garantia de uma promessa que jamais se buscaria romper, e no caso de que uma das partes o rompesse, a esta se acusaria de ter cometido um ato de perfídia e, consequentemente, de perjúrio:

As condições (condiciones/conditiones) pertencem com toda propriedade às testemunhas e recebem este nome derivado de condicere (dizer conjuntamente), porque não é somente uma testemunha a que presta juramento, mas duas ou mais. Pois a palavra não está posta na boca de um, mas na de duas ou de três testemunhas. E se chamam "condições" porque as afirmações das testemunhas concordam entre si, como se disséssemos "concorrência de testemunhas" [...]. Sacramento é a garantia de uma promessa; a denominamos "sacramento" porque romper o que um prometeu é um ato de perfídia (Isid., Etym., V, 24, 29, 31).

Pérfido: porque é um falso e não guarda a palavra empenhada, como se disséssemos que perde a sua fidelidade. Perjuro: porque jura em falso, ou seja, jura com falsidade (Isid., Etym., X, 222).

O juramento não se opõe ao preceito divino; mas se adquirimos o costume de jurar, incorremos no pecado de perjúrio. Pois nunca deve jurar quem teme cometer perjúrio (Isid., Sententiae, II, 31, 2).

Tratava-se de uma prática muito recorrente contra a autoridade régia hispanovisigoda, segundo os relatos encontrados na documentação eclesiástica e laica, aspecto que realçava a acentuada disputa existente entre as várias gentes hispano-visigodas

\footnotetext{
${ }^{6}$ Dentre o conjunto de fórmulas jurídicas existentes na compilação das Formulae Visigothicae, documentos datados de meados do século VII, encontramos a Conditiones Sacramentorum, que nos mostra o estabelecimento de um pacto entre duas ou mais partes diante de signos divinos. Portanto, trata-se de uma fórmula que reconhece e consolida um juramento de fidelidade mútuo que seria, em termos gerais, o mesmo proferido diante da autoridade régia no momento de sua ascensão ao trono hispano-visigodo.
} 
pelo sólio régio. ${ }^{7}$ Enfrentamentos políticos que colocavam em xeque mais o ocupante da função régia e menos a realeza, embora esta última sofresse importantes danos em termos institucionais com a presença de reis sem apoios significativos para governar. Para contrapor tais ameaças, se observa, no conjunto da documentação laica e eclesiástica hispano-visigoda, o incremento do reforço ideológico da supremacia régia sobre o conjunto da sociedade, já que o rei, de acordo com o discurso oficial, recebia, em termos teóricos, o poder de Deus:

Deus concedeu aos príncipes a soberania para o governo dos povos, quis que eles estivessem à frente daqueles que compartilham sua mesma sorte de nascer e morrer. Portanto, o principado deve favorecer os povos e não os prejudicar; não os oprimir com a tirania, mas velar por eles sendo condescendente, a fim de que seu distintivo poder seja verdadeiramente útil e empreguem o dom de Deus para proteger aos membros de Cristo. Certo que membros de Cristo são os povos fiéis (Isid., Sententiae, III, 49, 3).

Contudo, analisando os acontecimentos ocorridos entre os reinados de Chintila e Recesvinto (636-672), observamos uma considerável quantidade de revoltas e conjurações promovidas exatamente por aqueles que juravam fidelidade ao rei, demonstrando uma significativa distância entre o discurso eclesiástico, idealista e tendente à consolidação de uma realeza institucionalmente superior, e a prática política marcada pela confrontação e pelas disputas levadas a cabo pelas gentes hispano-visigodas.

Assim, parece-nos certo dizer que a infidelidade aristocrático-nobiliárquica aparecia, em termos práticos, como um autêntico morbo político com consequências nefastas ao poder régio (FRIGHETTO, 2016, p. 124-134). ${ }^{8}$ Neste caso, a formulação e a imposição de leis por parte da instituição régia, tanto no âmbito laico quanto no eclesiástico, que castigavam como crime tanto a quebra quanto o não cumprimento de juramentos de fidelidade de parte dos integrantes da sociedade política hispano-visigoda, partiam da vontade e, também, da necessidade do rei de conter tais iniciativas apontadas como pérfidas e que ameaçavam tanto a integridade física do monarca como a de seus familiares e aliados mais próximos. De fato, o atentado contra a vida do rei e de todos aqueles que faziam parte de seu grupo sociopolítico era apontado como uma das características do perfil do infiel, como foi o caso do Duque Argimundo no reinado de Recaredo (586-601), descrito por João de Bíclaro (Crônica, a.590, 3) da seguinte forma:

\footnotetext{
7 Plural de gens, as gentes eram, na verdade, as grandes famílias aristocráticas hispano-visigodas que participavam ativamente das ações políticas no regnum gothorum.

${ }^{8}$ Morbo que pode ser traduzido como "enfermidade", segundo Isidoro de Sevilha: "No nome genérico de 'enfermidade' (morbi) se resumem todos os males do corpo. Os antigos lhe deram o nome de morbus (enfermidade) para mostrar com esta denominação a mortis vis ou a força da morte que da enfermidade se origina. Entre a saúde e a enfermidade está o tratamento curativo que, se não é adaptado à enfermidade, não cura" (Isid., Etym., IV, 5, 2).
} 
O reinado do ortodoxo Recaredo foi abalado por um problema interno provocado por um pretendente ao trono. Um duque provincial, de nome Argimundo, integrante do cubículo, atentou de forma tirânica contra a vida do rei Recaredo para assumir o trono [...], primeiramente foi duramente interrogado, depois foi cruelmente decalvado, teve a destra amputada e desfilou montado em um asno pela urbe toledana para servir de exemplo aos soberbos.

Além desta atitude de infidelidade, que afetaria diretamente a pessoa do rei, destacamos também um caso muito recordado pela documentação hispano-visigoda, o de integrantes aristocráticos e nobiliárquicos que provocavam alguma ação violenta no interior do reino ou em suas áreas limítrofes e que contavam, em ambos os casos, com apoio de inimigos externos (FRIGHETTO, 2019, p. 102-103). Iniciativas pessoais, por certo, mas diretamente relacionadas ao desenvolvimento das disputas políticas internas que estimulariam o esquecimento por parte de certos grupos aristocráticos e nobiliárquicos das promessas juradas e sagradas ao rei de defendê-lo e, também, à patria e às gentes hispano-visigodas. ${ }^{9}$ Logo, o não cumprimento do que foi estabelecido no juramento de fidelidade ao rei feito por todos os integrantes da sociedade política hispano-visigoda geraria uma reação legítima da autoridade régia apresentada nas leis laicas e eclesiásticas, que, ademais de configurarem o crime de infidelidade, apontavam uma série de castigos que deveriam ser impostos aos acusados de cometerem aquele crime contra o rei, contra a patria e contra as gentes, como no caso de bispos que enviassem mensageiros ao exterior sem o consentimento régio:

Os bispos que limitem com os inimigos, excetuando aqueles que o rei autorizar, não se atrevam a receber ou enviar ocultamente qualquer mandato ao povo estrangeiro; e se algum for surpreendido e convicto, dando aviso ao rei, será castigado no concílio com uma pena proporcional ao seu delito (Concílio IV de Toledo, a.633, c.30).

Ora, os castigos que poderiam ser impostos àqueles acusados de cometerem atos de infidelidade contra o poder régio aparecem com destaque na L.V., II, 1, 6, promulgada em 643, no segundo ano do reinado de Chindasvinto, ${ }^{10}$ e com algumas modificações no cânone 1 do VII Concílio de Toledo, do ano de 646. De acordo com o texto da lei, apresentada na $L$. $V$., recuperava-se uma disposição apresentada nos tempos do reinado de Chintila, provavelmente a mesma indicada no cânone 12 do VI Concílio de Toledo de 638, estabelecendo penalidades e castigos contra aqueles que passavam ao inimigo

\footnotetext{
${ }^{9}$ A ideia de "pátria" na documentação hispano-visigoda está relacionada tanto à conotação local como a uma perspectiva mais ampla em termos espaciais. Os casos analisados neste estudo vinculam-se à construção identitária de uma patria gothorum, comum e original das gentes gothorum. De acordo com o hispalense, "[...] o nome pátria se deve a que é comum a todos os que nela nasceram" (Isid., Etym., XIV, 5, 19).

${ }^{10}$ Lei que tem por título: "Daqueles que fogem depois de agirem de forma insolente contra o principe, as gentes e a pátria" (De his qui contra principem vel gentem aut patriam refugiunt, vel insolentes existunt).
} 
e que desde os limites do reino realizavam incursões que provocavam instabilidade e confusão internas:

Quantos dos godos abandonam a sua pátria, e quantos são estimulados a fugirem pela soberba para reduzirem a pátria lançando mão de inimigos externos. Diante de tamanha temeridade, a loucura destes transgressores não deve ficar impune e por isso sancionamos esta lei no segundo ano de nosso reinado, amparados naquela já promulgada em anos passados pelo príncipe Chintila, de boa memória, contra aqueles que usam gentes inimigas, desde terras externas que vão e retornam de forma alucinada contra as gentes e a pátria godas (Lex Visigothorum, II, 1, 6 - promulgada pelo rei Chindasvinto).

Portanto, tivemos por bem ordenar agora, de comum acordo, que qualquer que pertencer à ordem clerical, em qualquer grau do maior ao menor, que em qualquer ocasião passar ao território de outro povo para desde ali exigir com soberba seu regresso ou qualquer outra coisa, ou tratar de fazer ou fizer de algum modo algo que naquela ocasião possa prejudicar especialmente ao povo dos godos, a pátria ou ao rei (Concílio VII de Toledo, a. 646, c.1).

A audácia dos perversos corações, ou a malicia de seus pensamentos, ou a consciência culpada, busca refúgio entre os inimigos. Pelo qual, qualquer que cometer algum destes delitos reforçando o poder dos adversários e causando algum dano nos bens da pátria, ou a seu povo, se voltar à jurisdição do rei ou da nação, será excomungado, recluído e submetido às obrigações de uma longa penitência (Concílio VI de Toledo, a.638, c.12).

É inquestionável que se tratava de um caso de infidelidade contra o rei, contra a patria e contra as gentes que merecia uma atenção especial por parte do poder régio hispano-visigodo. Tais infiéis, apresentados como criminosos, também eram descritos na lei de Chindasvinto como prófugos e o contexto desta norma legal estava diretamente relacionado aos acontecimentos que haviam culminado com a elevação de Chindasvinto ao poder no reino hispano-visigodo. Com efeito, os momentos iniciais do reinado de Chindasvinto foram marcados por atitudes de força, considerada pela documentação coeva como uma ação violenta e tirânica:

Um dos primates, de nome Chindasvinto, reuniu um grande número de senadores godos e junto com o povo alçou reino na Hispania, depondo Tulga e o fez clérigo com a tonsura [...]. Contra o vício eliminou duzentos primates godos e quinhentos mediocres. Conhecedor do morbo gothorum, Chindasvinto não cessou de trucidar pelo gládio (Fredegarii Scholastici, Chronica, 82).

A deposição forçada do jovem rei Tulga no ano de 642, em decorrência de um levante liderado pelo primate Chindasvinto, ${ }^{11}$ acabou gerando um confronto entre segmentos

\footnotetext{
${ }^{11} \mathrm{O}$ termo primate diz respeito à condição de Chindasvinto de líder de uma importante gens hispano-visigoda. Na perspectiva isidoriana, seria sinônimo de "primeiro": "Primus (primeiro), como se disséssemos praeminens (preeminente)" (Isid., Etym., X, 207).
} 
aristocráticos e nobiliárquicos que apoiavam o novo soberano e aqueles que defendiam a causa do que fora apeado do poder (FRIGHETTO, 2018, p. 394-397). Embate que tinha uma clara motivação vinculada às disputas sobre o patrimônio régio e a concessão de benefícios tanto a um grupo quanto a outro. Os sinais desta disputa à volta dos problemas patrimoniais já apareciam indicados nos Concílios V e VI de Toledo e davam conta da existência de ameaças contra os fiéis diretamente relacionados ao rei, revelando uma debilidade efetiva da autoridade régia de impor limites e freios àqueles conflitos:

Com a mesma previsão, damos esta norma em favor dos fiéis aos reis, que qualquer que sobreviver aos reis não deve sofrer nenhum prejuízo nas coisas justamente adquiridas ou recebidas da generosidade do rei, pois permitindo que injustamente se arrebate o prêmio dos fiéis ninguém quererá servir aos reis com prontidão e fidelidade (Concílio $V$ de Toledo, a. 636, c.6);

Não apenas é desumano, mas também injusto defraudar aos fiéis em seu prêmio e, portanto, não sendo coisa estéril o prêmio outorgado à fidelidade, tanto nas coisas divinas como nas humanas, parece digno que olhemos pelos fiéis ao rei com nosso ditame. Portanto, confirmando o que no ano primeiro de nosso senhor sereníssimo rei decretou o Santo Concílio, nenhum dos que obedecerem com fiel obséquio e sincero serviço às vontades e mandatos do príncipe e prestarem vigilância e custodiarem sua vida com todas as forças, não sejam, pelos sucessores no reino, privados injustamente de seu cargo nem dos bens que possuíram (Concílio VI de Toledo, a. 638, c.14).

No momento em que um dos grupos aristocrático-nobiliárquicos se sobrepôs ao outro, provocando o alijamento de Tulga do poder régio, uma significativa parcela dos apoiantes do rei deposto viram-se obrigados a empreender a fuga, abandonando suas terras e transformando-se em inimici hostis de Chindasvinto e seus seguidores. Por outro lado, aqueles que permaneceram e tentaram resistir ou negociar acabaram dando razão aos que escaparam, pois a ferocidade e a violência de Chindasvinto contra os seus rivais políticos foi tamanha que a documentação o apodou como o demolidor dos godos (Crônica Moçárabe, a.754, 22), título que por si só revela o ânimo do novo rei com relação a possíveis rivais e opositores.

\section{O desterro, sinônimo de infidelidade?}

Os aristocratas e os nobres descritos pela L.V., II, 1, 6, que são denominados no cânone 1 do VII Concílio de Toledo como fugitivos e pérfidos provocadores de distúrbios e conflitos nas áreas fronteiriças do reino, têm um paralelo com os que denominaríamos como desterrados. Esta é uma hipótese baseada nas definições tradicionais relativas ao desterro, caracterizado na documentação hispano-visigoda como uma atitude pessoal 
que levava o indivíduo a abandonar e distanciar-se de sua patria original, de seu lar, possivelmente para evitar a imposição de uma pena e de castigos considerados muito duros e injustificáveis desde a ótica do acusado:

Extorris (desterrado), o que está distante de sua terra; equivale a exterris. Não obstante, se emprega apropriadamente extorris para significar que foi expulso e alijado de sua terra pátria pela força ou pelo terror; em consequência, extorris é o que foi expulso de sua terra. Extorris, o que está fora de sua terra ou longe de suas fronteiras, porque foi desterrado (Isid., Etym., X, 85-86).

Assim, o desterro pode ser entendido como uma saída meio obrigada, meio voluntária, que seria razoável aos aristocratas e nobres acusados de infidelidade e que evitariam jogar com a sorte e com a própria vida em um choque direto com forças régias que poderiam ser mais poderosas que as suas. Fugindo para regiões que estavam fora do alcance do poder e da justiça régia, tanto o aristocrata quanto o nobre, de acordo com seu status e a sua condição político-familiar, poderiam contar com consideráveis apoios aristocráticos e nobiliárquicos entre as gentes estrangeiras que lhes dariam abrigo e apoio militar, com os quais os prófugos hispano-visigodos poderiam atacar e assolar, inclusive, as áreas que antes estavam integradas aos seus domínios patrimoniais. Neste caso específico, que envolveria o ataque promovido por aristocratas e nobres hispanovisigodos desde territórios externos ao regnum gothorum, com o auxílio de hostes forâneas - alienae gentis -, caracterizava-se o crime de infidelidade extrema praticado por hispano-visigodos que haviam se desterrado para agirem contra o seu rei, a sua patria e as gentes hispano-visigodas. E sendo capturado na decorrência do fracasso de alguma destas ações de pilhagem e de saque, que certamente provocavam muita confusão e graves danos socioeconômicos nas províncias atacadas, o aristocrata/nobre desterrado sofreria o peso da lei promulgada por Chindasvinto, que contemplava a imposição de castigos corporais duríssimos, que poderiam culminar com a sua morte ou, no caso de obter a misericórdia régia, sofrer a perfuração ocular e a perda da liberdade:

[...] aqueles que agirem nos limites da pátria provocando conturbações e conflitos contra o reino e contra as gentes dos godos e forem capturados [...]: qualquer que seja o desajustado réu, lhe será imposta a intratável sentença de morte, comutada pela piedade do principe sendo-Ihe concedida a vida em troca da perfuração ocular e a perda da liberdade (Lex Visigothorum, II, 1, 6 promulgada pelo rei Chindasvinto).

Por outro lado, quando observamos o disposto no cânone 1 do VII Concílio de Toledo, ocorrido três anos após a promulgação da L.V., II, 1, 6 de Chindasvinto, verificamos a substituição dos castigos corporais e da penalidade capital por condenações de 
excomunhão e de anátema perpétuo, seguindo o que fora definido no IV Concílio de Toledo de 633 sobre a atuação dos bispos em assuntos judiciais:

\begin{abstract}
Muitas vezes os principes encomendam seus assuntos aos bispos contra alguns réus de alta majestade; mas porque os bispos foram eleitos por Cristo para o ministério da salvação, somente admitiram que os reis lhes nomeiem juízes quando prometa sob juramento o perdão da pena capital (Concílio IV de Toledo, a. 633, cânone 31).

[...] ou para que causassem algum dano ao povo dos godos, à pátria ou ao príncipe depois de sua fuga e a todos àqueles que se sabe têm aconselhado a perseverança em tais maldades, todos estes sujeitos serão imediatamente privados do grau de suas honras, para que outro em seguida possa ocupar perpetuamente o posto no qual aqueles prestavam seus serviços, e ao mesmo transgressor obrigado à penitência, no caso de arrepender-se do mal que cometeu e fizer penitência pontualmente, até o dia de sua morte se lhe dará a comunhão, mas ao fim de sua vida (Concílio VII de Toledo, a. 646, c. 1).
\end{abstract}

Ora, a existência de uma normativa conciliar que estabelecia este tipo de atuação episcopal nos faz pensar na possibilidade de que tal princípio nem sempre foi seguido pelos representantes episcopais, ainda mais se recordarmos que tanto os bispos quantos os abades de comunidades monásticas reconhecidas e clérigos estavam integrados a grupos aristocráticos com interesses políticos bem definidos. Além disso, observamos que a documentação laica e eclesiástica hispano-visigoda é pouco clara ao informar a condição de desterrado de um aristocrata ou nobre, apontando-o, geralmente, com o adjetivo de infiel. Ou seja, devemos analisar se existem informações mais precisas sobre aquele aristocrata/nobre apontado como infiel, se ele abandonou o reino e refugiou-se em áreas que escapavam ao controle régio hispano-visigodo, condições que o tornavam um desterrado, para dali iniciar ações militares contra o reino com o auxílio de agentes externos que acabavam transformando-o, também, em um agressor. Partindo destes detalhes e conectando-os aos castigos impostos aos traidores e apresentados na $L$. $V$., II, 1, 6, podemos encontrar casos de integrantes do ambiente aristocrático-nobiliárquico hispano-visigodo que desde regiões externas ao regnum gothorum o atacaram, sendo acusados de infidelidade por ameaçarem a integridade do reino e a vida do próprio rei.

Um caso emblemático e que preenche todos os elementos que apontamos foi o da rebelião encabeçada por Froya nos primórdios do reinado de Recesvinto. Os detalhes deste levante e as suas consequências foram apresentados em uma epístola escrita por Taio de Zaragoza a Quirico de Barcelona, que surge como prefácio aos cinco livros 
das Sentenças escritas pelo cesaraugustano. ${ }^{12} \mathrm{Nela}$, Taio descreve aquele tempo como marcado pela confusão e pela virulência, no qual surge Froya, assim descrito:

[...] um tirano, Froya, homem pestífero e de cabeça insana, virulento, provocador da cizânia e louco pela sua perversão, contrário ao ortodoxo e reverente ao culto de Deus principe Recesvinto, cuja soberba o levou a agredir a patria (Taio, Sententiae, Praef., 2).

Apesar desta interessante indicação que associava a ação de Froya a uma tentativa de usurpação tirânica do poder, chama-nos a atenção outra informação legada pelo cesaraugustano e que faz referência tanto ao grupo que prestou apoio ao usurpador quanto ao espaço do qual foram iniciadas ações militares contra o regnum gothorum. Segundo o bispo de Zaragoza, a agressão perpetrada por Froya recebera apoio das tribos vascas estabelecidas nas regiões pirenaicas e provocaram inúmeros prejuízos e danos na Provincia Tarraconense, chegando, inclusive, a cercar e sitiar a capital provincial, Zaragoza:

Para a sua enlouquecida causa contou com o apoio dos vascos estabelecidos nos montes Pirineus, provocando muitos saques e uma grande destruição nas terras da Ibéria. Oh, quanta dor! [...] O sangue de muitos cristãos foi derramado [...], inúmeros foram capturados e reduzidos à servidão. Muitos templos de Deus foram atacados, vários altares destruídos [...]. Os muros da urbe de Zaragoza os conteve (Taio, Sententiae, Praef., 2-3).

Ou seja, segundo as informações de Taio, os ataques realizados por Froya, com apoio de tribos vascas contra o território da Tarraconense, sugerem que estes partiram de áreas da Vasconia e, consequentemente, de regiões externas à hegemonia do regnum gothorum. Nesse sentido, podemos pensar que Froya se desterrara às terras dos vascos, obtendo ali apoio às suas ações militares contra Recesvinto. E seguindo com o relato do cesaraugustano, o próprio rei deslocou-se à Tarraconense e conseguiu derrotar tanto a Froya quanto aos vascos:

[...] contamos com o auxílio da destra de nosso piíssimo príncipe contra aquela impiíssima hoste. Com os pedidos e as orações dos pobres a Deus o misericordioso príncipe nos auxiliou. E com o seu fortíssimo apoio e a sua onipotência aplacou a sublevação; e repentinamente os autores daquela tirânica superstição foram condenados: enquanto recebia a palma da vitória, sobre aqueles era imposta a ignomínia e uma atrocíssima morte. Deus os destruiu com a sua destra (Taio, Sententiae, Praef., 3).

\footnotetext{
${ }^{12}$ Adjetivo que significa "habitante de Caesaraugusta" (Zaragoza).
} 
Figura 1 - Rebelião de Froya nos primórdios do reinado de Recesvinto

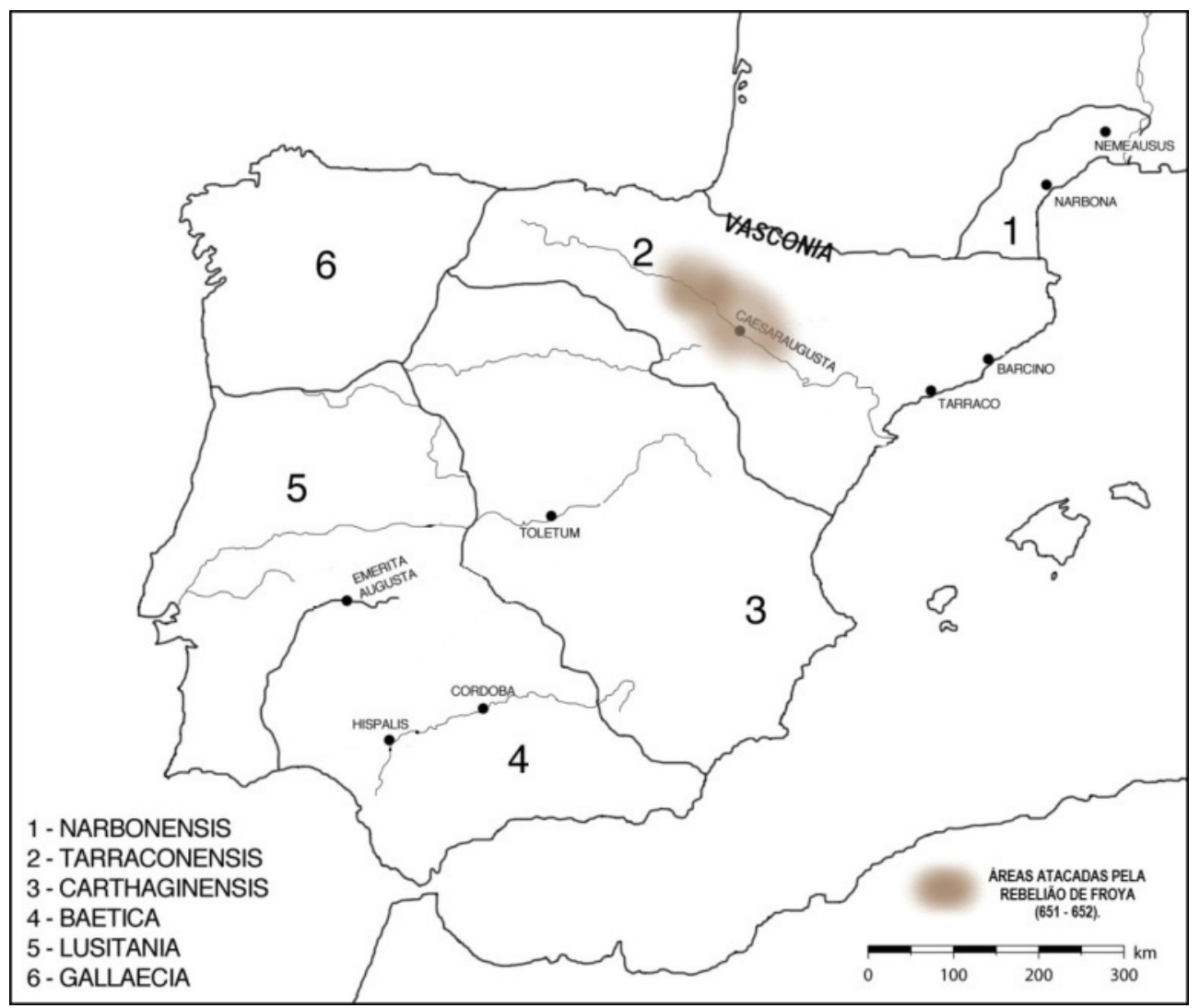

Fonte: Mapa de autoria própria.

Ao que tudo indica, de acordo com o relato de Taio, Froya foi derrotado, capturado e foi-Ihe imposta a pena capital prevista na $L$. $V$., II, 1, 6. Um castigo aplicado aos que cometessem o crime de infidelidade, agravado, neste caso, pelas tentativas de usurpação e de ataques contra o reino hispano-visigodo. Embora regular, a aplicação da pena de morte a Froya por parte da autoridade régia foi vista como excessiva pelos segmentos aristocráticos-nobiliárquicos hispano-visigodos, que buscaram flexibilizar penalidades e castigos extremos e definitivos. Amparados no princípio isidoriano que afirmava que "as virtudes régias são principalmente duas: a justiça e a piedade. Não obstante, deve-se se destacar nos reis a piedade, pois a justiça, por sua própria essência, é severa" (Isid., Etym., IX, 3, 5). Os representantes episcopais reunidos no VIII Concílio de Toledo de 653, celebrado um ano após a imposição da pena capital a Froya, conclamavam a autoridade régia a conceder a piedade aos refugas e traidores acusados de cometerem atos de infidelidade contra o rei, a patria e as gentes:

Ao tratar do segundo ponto se nos apresentou um assunto tão difícil como importante, isto é, da diversidade de pareceres sobre os expatriados e traidores e se discutiu com muito calor se era possível mitigar a sentença de condenação daqueles [...]. Mas que a severidade das penas possa e deva ser dispensada, 0 
aconselha tanto o horrível das obrigações e das queixas como o recomendam os preceitos da própria autoridade divina [...]. Resta, pois, que nosso parecer se incline ali onde se abre o caminho à misericórdia [...] e conceda esta mitigação indulgente, deixamos nas mãos do glorioso príncipe a realização da misericórdia, pois já que Deus lhe abriu a possibilidade de ter misericórdia, não negue ele mesmo os remédios da piedade, os quais perdurarão moderados pela discrição do principe que concederá a misericórdia em certo grau, mas sem que jamais o povo ou a pátria sofram por causa dos indultados nenhum perigo ou perda (Concílio VIII de Toledo, a. 653, c.2).

A dureza dos castigos imputados aos acusados de cometerem o crime de infidelidade contra o rei, especialmente após o juízo de Froya, mobilizou os integrantes da aristocracia e da nobreza laico-eclesiástica hispano-visigoda na promoção da flexibilização das penas, particularmente a imposição da pena capital. Parece-nos certo indicar que a lei promulgada por Chindasvinto, em 643, e levada a termo por Recesvinto no episódio da rebelião de Froya, relacionava, de forma direta, os atos de infidelidade cometidos contra a autoridade régia com todos aqueles que haviam se desterrado do reino hispano-visigodo. Observamos uma associação maléfica apresentada pela norma legal entre os denominados como refugas, desterrados, colocados em equivalência aos infiéis que praticavam ações de desestabilização do regnum gothorum desde áreas externas, contando, inclusive, com apoio daqueles que eram considerados pelo poder régio hispano-visigodo como verdadeiros inimicus hostes, que ameaçavam a integridade da patria gothorum. Evidente que, ao se desterrar das terras do reino, o aristocrata ou nobre hispano-visigodo rompia com as promessas de fidelidade estabelecidas em juramento e dirigidas à autoridade régia, porém colocá-lo no mesmo patamar daquele que atacava o território rompia com todo e qualquer princípio de misericórdia e de prudência, que era associado ao bom governante católico. Por isso, a fim de se evitar o uso desmedido e indiscriminado da força régia, que poderia ser vinculada à brutalidade e à violência características dos maus governantes, os padres conciliares reunidos no Concílio VIII de Toledo impuseram certas travas para coibir prováveis abusos por parte do poder régio hispano-visigodo contra possíveis acusados de romperem os seus juramentos de fidelidade ao rei e estabeleceram a necessidade de que se impusesse o perdão das penas de morte e de amputação de algum membro daqueles:

[...] qualquer juramento feito em favor do poder real ou em defesa do povo ou da pátria, bem sejam anteriores a este decreto, bem posteriores, tem de ser observados irremissivelmente com toda a custódia e vigilância, mas completamente livres daqueles que incluíam a amputação de um membro ou a sentença de morte e com objeto da astuta maldade dos corações perversos, não nos impute alguma vez a culpa de perjúrio e afirme que esta decisão não provem das normas da santa fé (Concílio VIII de Toledo, a.653, c.2). 
Dessa forma, podemos dizer que as normas conciliares exaradas no VIII Concílio de Toledo concorriam com as leges promulgadas pelo poder régio, particularmente quando aquelas atingiam duramente os integrantes do universo aristocrático do reino hispanovisigodo de Toledo. Por certo que a $L$. $V$., II, 1, 6 de Chindasvinto pode ser enquadrada como uma lei promulgada em um período de exceção, demonstrando a verdadeira face da atitude tirânica promovida por aquele, e que acentuou ainda mais as rusgas e as diferenças entre os grupos sociopolíticos hispano-visigodos. A revolta de Froya seria um reflexo desta postura régia, que foi, também, aplicada pelo sucessor e filho de Chindasvinto, Recesvinto, contra um rebelde desterrado. O universo episcopal e eclesiástico hispano-visigodo, longe de sobrepujar a autoridade régia, ofereceu uma alternativa jurídica mais pacífica para reduzir a tendência régia de promover uma reação descomunal, que culminava com a imposição da morte ou de castigos corporais extremos aos que eram considerados infiéis desterrados. Ao fim e ao cabo, a proposta episcopal encontrava respaldo no pensamento isidoriano, muito oportuno na busca pelo equilíbrio político e institucional, que favoreceria a todos, ao rei, à aristocracia e à nobreza laica e eclesiástica:

Em muitos se descobre o delito de conspirar contra os principes; mas como Deus quer colocar à prova a clemência dos soberanos, àqueles lhes permite por enganos e a estes não os abandona. Da maldade dos primeiros tira um bem para os segundos, os quais perdoam com exemplar paciência as culpas que aqueles cometem (Isid., Sententiae, III, 50, 2).

\section{Conclusão}

Verificamos, portanto, a existência de uma interessante relação entre o contexto histórico no qual se desenvolviam as ações políticas e as normas legais publicadas pela autoridade régia hispano-visigoda, e que surgiam como resposta às ameaças que se impunham. Como observamos, o período histórico balizado entre os reinados de Chintila e Recesvinto foi marcado por intensos conflitos entre os grupos aristocráticos e nobiliárquicos hispano-visigodos, que atingiram a própria figura régia e, consequentemente, debilitaram a realeza desde a perspectiva político-institucional. Por isso, a promulgação e a revisão das leis por parte do poder régio pode ser entendida como um sintoma da fragilidade política da realeza, visto que a necessidade de criar, manter e renovar castigos para coibir as atitudes de rebeldia contra a autoridade régia demonstra a ausência efetiva e prática do consenso entre as gentes hispano-visigodas e a multiplicação de conflitos que podem ser uma via explicativa para entendermos os motivos que levaram a monarquia hispanovisigoda ao desaparecimento nos primórdios do século VIII. 
Dos diversos crimes apontados pelas leis laicas e eclesiásticas hispano-visigodas, apresentadas na $L$. $V$. e nas atas dos Concílios hispano-visigodos, optamos por analisar aqueles que eram praticados pelos indivíduos pertencentes aos mais altos segmentos sociopolíticos do regnum gothorum contra o rei, descritos como atos de traição e de perfídia causados pela ruptura do juramento de fidelidade feito ao monarca. Uma série de atitudes, pessoais ou coletivas, realizadas ou pensadas por aristocratas e nobres poderia ser enquadrada, segundo a perspectiva régia, como crime de infidelidade: atentar contra a vida do rei e de sua família; fugir para regiões distantes e limítrofes e desde aquelas promover ataques contra o interior do reino, contando, para tanto, com o auxílio dos inimigos externos. Para reprimi-las, as normas legais laicas impunham castigos severos, como a morte ou outros castigos corporais que substituiriam a pena de morte, como a perfuração ocular, a extirpação da destra e outros tipos de açoites, além da decalvação e de outros castigos corporais e psicológicos. Isso sem esquecermos a perda de honras, títulos e patrimônios, que, para aristocratas e nobres, era equivalente aos piores castigos físicos.

Diante das ameaças que poderiam culminar com a perda da vida, aristocratas e nobres hispano-visigodos, acusados de cometerem atos de infidelidade contra o rei, faziam o movimento de abandono e de fuga do regnum gothorum, refugas que deixavam suas terras e os seus bens e que passavam à condição de desterrados. Logo, a fuga tinha como sinônimo o próprio desterro, apontado pelo hispalense como abandono da pátria por motivos pessoais. Válido tanto para os laicos quanto para os eclesiásticos, o desterro acabou sendo associado à própria atitude de infidelidade, conforme a indicação feita na $L$. $V$., II, 1, 6 de Chindasvinto, e que também foi apontada nos cânones desde o Concílio IV de Toledo, de 633, até o Concílio VIII de Toledo, de 653. Esta confusão gerou, por certo, um acirramento das posições régias sobre o conjunto dos desterrados, embora nem todos agissem de maneira irascível e violenta contra o reino hispanovisigodo. Contudo, devemos dizer que existiram casos emblemáticos de aristocratas e nobres hispano-visigodos que reagiram à sua necessidade de fuga com virulência e brutalidade, como no exemplo de Froya. Este aristocrata/nobre hispano-visigodo, de acordo com o relato oferecido por Taio de Zaragoza, se desterrou nos primórdios do reinado de Recesvinto e, desde as terras ocupadas pelas tribos vascas, realizou, com a ajuda daquelas, diversas ações de saque contra a província da Tarraconense, levando o pânico, a confusão e a instabilidade política ao interior do regnum gothorum. A derrota militar de Froya, sua captura e a sua imediata eliminação física acenderam o alerta entre os segmentos aristocráticos e nobiliárquicos hispano-visigodos, visto que as garantias para a realização de um juízo equilibrado e efetivamente justo inexistiam em casos como 
os de Froya. O receio pelo endurecimento e pelo acirramento dos castigos por parte da justiça régia, ao lado da necessidade de se buscar o consenso e a concordia internas para que se alcançasse a pax que, de fato, inexistia desde a deposição de Tulga (642) e da chegada ao poder de Chindasvinto, fez com que o conjunto aristocrático-nobiliárquico hispano-visigodo buscasse alternativas morais e jurídicas para conter a própria fúria régia, entendida como excessiva e contrária à lógica do bom governante, que deveria pautarse, sobretudo, pela misericórdia e pela piedade em relação aos seus oponentes. Por isso, podemos dizer que o cânone $2^{\circ}$, do VIII Concílio de Toledo, de 653, buscou recuperar uma norma canônica anterior, apresentada no IV Concílio de Toledo, de 633, para tentar limitar os excessos da ação régia amparada pela L.V., II, 1, 6, de Chindasvinto, contra os que fossem acusados de traição e de infidelidade. $E$ ao que tudo indica, se lançarmos um olhar sobre o conjunto do longo reinado de Recesvinto, verificaremos que, ao menos por algum tempo, encontrou-se um equilíbrio político e institucional que aproximou o poder régio dos segmentos aristocrático-nobiliárquicos hispano-visigodos, tendo na promulgação da revisão do Liber Iudiciorum/L.V. de 654 um de seus sinais mais significativos.

Assim, podemos dizer que tanto as leis laicas e eclesiásticas quanto a documentação de caráter político-moral analisadas ao longo deste estudo revelam a intensa contradição e o confronto direto entre a autoridade régia e os grupos aristocrático-nobiliárquicos procedentes dos ambientes laico e eclesiástico do reino hispano-visigodo de Toledo. Antagonismo que acabou incrementando, de forma direta e paulatina, o esfacelamento político e institucional da autoridade régia hispano-visigoda.

\section{Referências}

\section{Documentação textual}

CONCÍLIO IV DE TOLEDO. a. 633. In: VIVES, J.; MARÍN, T.; MARTINEZ, G. (Ed.). Concilios Visigoticos e Hispano-Romanos. Barcelona: Consejo Superior de Investigaciones Científicas, 1963.

CONCÍLIO V DE TOLEDO. a. 636. In: VIVES, J.; MARÍN, T.; MARTINEZ, G. (Ed.). Concilios Visigoticos e Hispano-Romanos. Barcelona: Consejo Superior de Investigaciones Científicas, 1963.

CONCÍLIO VI DE TOLEDO. a. 638. In: VIVES, J.; MARÍN, T.; MARTINEZ, G. (Ed.). Concilios Visigoticos e Hispano-Romanos. Barcelona: Consejo Superior de Investigaciones Científicas, 1963. 
CONCÍLIO VII DE TOLEDO. a. 646. In: VIVES, J.; MARÍN, T;; MARTINEZ, G. (Ed.). Concilios Visigoticos e Hispano-Romanos. Barcelona: Consejo Superior de Investigaciones Científicas, 1963.

CONCÍLIO VIII DE TOLEDO. a. 653. In: VIVES, J.; MARÍN, T.; MARTINEZ, G. (Ed.). Concilios Visigoticos e Hispano-Romanos. Barcelona: Consejo Superior de Investigaciones Científicas, 1963.

CRÔNICA MOÇÁRABE. a.754. In: LOPEZ PEREIRA, J. E. (Ed.). Cronica Mozarabe de 754. Zaragoza: Anubar, 1980.

FREDEGARII SCHOLASTICI. Epitomi et Chronicum. In: MIGNE, J.-P. (Ed.). Patrologia Latina LXXI. Paris: Ramos, 1849.

ISIDORO DE SEVILHA. Etimologias. In: DIAZY DIAZ, M.; OROZ RETA, J.; MARCOS CASQUERO,

M. (Ed.). San Isidoro de Sevilla. Madrid: Biblioteca de Autores Cristianos, 1982.

ISIDORO DE SEVILHA. Sentenças. In: CAMPOS, J.; ROCA, I. (Ed.). Santos Padres Españoles II:

San Leandro, San Isidoro, San Fructuoso. Madrid: Biblioteca de Autores Cristianos, 1971.

JOÃO DE BICLARO. Crônica. In: CAMPOS, J. Juan de Biclaro. Obispo de Gerona. Su vida y su obra. Madrid: CSIC, 1960.

LEX VISIGOTHORUM. In: HERCULANO, A. (Ed.). Portugaliae Monumenta Historica. Leges et Consuetudines. V. I, T. 1. Lisboa: Typis Academicis, 1856.

TAIO. Sententiarum libri quinque. In: MIGNE, J.-P. (Ed.). Patrologia Latina LXXX. Paris: 1849.

\section{Obras de apoio}

BARBERO, A.; VIGIL, M. Sobre los orígenes sociales de la Reconquista. Barcelona: Ariel, 1988. BARROS, J. D'A. Fontes históricas. Introdução aos seus usos historiográficos. Petrópolis: Vozes, 2019.

BOBBIO, N. Dicionário de política. Brasília: UNB, 1998. 2 v.

FEBVRE, L. Combates pela história. Lisboa: Presença, 1989.

FERNÁNDEZ SEBASTIÁN, J. Historia, historiografía, historicidad. Conciencia histórica y cambio conceptual. In: CORTINA, M. S (Coord.). Europa del sur y América Latina: perspectivas historiográficas. Madrid: Biblioteca Nueva, 2014, p. 3564.

FRIGHETTO, R. O rei e a lei na Hispania visigoda: os limites da autoridade régia segundo a Lex Wisigothorum, II, 1, 8 de Recesvinto (652-670). In: GUIMARÃES, M. L.; FRIGHETTO, R. (Coord.). Instituições, poderes e jurisdições. I Seminário Argentina - Brasil - Chile de História Antiga e Medieval. Curitiba: Juruá, 2007, p. 117135. 
FRIGHETTO, R. Símbolos e rituais: os mecanismos do poder político no reino hispanovisigodo de Toledo (séculos VI-VII). Anos 90, v. 22, n. 42, 2015, p. 239-272.

FRIGHETTO, R. Quando a traição torna-se uma enfermidade: a infidelidade política e a prática do Morbo Gothorum no reino hispano-visigodo de Toledo (século VII). Revista Signum, v. 17, n. 1, 2016, p. 116-135.

FRIGHETTO, R. Da liberdade à reclusão: os espaços de confinamento no reino hispanovisigodo de Toledo (séculos VI-VII). In: SILVA, G. V. DA; SILVA; É. C. M.; LIMA NETO, B. M. (Org.). Usos do espaço no mundo antigo. Vitória: GM, 2018, p. 380402.

FRIGHETTO, R. Da infidelidade ao exílio: um exemplo de mobilidade forçada nos escritos de Valério do Bierzo (séc. VII). In: FRIGHETTO, R; SILVA, G. V. da; GUIMARÃES, M. L (Org.). As mobilidades e as suas formas na Antiguidade Tardia e na Idade Média. Vitória: GM, 2019, p. 97120.

GARCIA MORENO, L. A. El estado protofeudal visigodo: precedente y modelo para la Europa carolíngia. In: FONTAINE, J.; PELLISTRANDI, C. (Éd.). L'Europe héritière de l'Espagne wisigothique. Rencontres de la Casa de Velázquez. Madrid: Casa de Velázquez, 1992, p. 17-43.

GASCÓ, F. La crisis del siglo III y la recuperación de la Historia de Roma como un tema digno de ser historiado". Studia Historica - Historia Antigua, IV - V/1, Homenaje al Profesor Marcelo Vigil (I), 1986, p. 167171.

GROSSI, P. A ordem jurídica medieval. São Paulo: Martins Fontes, 2014.

KING, P. D. Derecho y sociedad en el reino visigodo. Madrid: Alianza, 1981.

PETIT, C. Crimen y castigo en el reino visigodo de Toledo. In: Arqueología, Paleontología y Etnografía: los Visigodos y su Mundo. Madrid: Comunidad de Madrid, 1998, p. 217237.

SANCHEZ-ALBORNOZ, Cl. El 'stipendium' hispano-godo y los orígenes del beneficio prefeudal. Buenos Aires: Facultad de Filosofía y Letras, 1947.

WARMALD, P. The Leges Barbarorum: law and ethnicity in the post-Roman West. In: GOETZ, H. W.; JARNUT, J.; POHL, W. (Ed.). Regna and Gentes. The relationship between Late Antique and Early Medieval people and Kingdoms in the transformation of the Roman world. Leiden: Brill, 2003, p. 21-53. 